\title{
Does the UK economy grow faster under a Conservative or Labour government?
}

\author{
Amr Saber Algarhi • Alexander Tziamalis* \\ Sheffield Hallam University, Sheffield, United Kingdom
}

Received: 1 July 2020

Revised: 11 November 2020

Accepted: 13 January 2021

\begin{abstract}
We use quarterly data from 1955 to 2019 to examine the performance of Conservative and Labour administrations in terms of real GDP growth in the United Kingdom. To account for fiscal lags in the legislation and implementation of new policies by each administration, we explore up to lag 8 in addition to an overlapping technique. Our main finding is that the UK economy has grown with a similar pace under both parties, however Labour governments seem to do better in tackling recessions and achieve a more consistent performance. Labour's advantage becomes more pronounced if we discount the effect of a large external shock, the 2008 Financial Crisis.
\end{abstract}

Keywords: Conservatives; GDP growth; Labour; partisan politics; UK government JEL Classification Codes: E65, N14, N44, O52

\section{Introduction}

Since the 1920s, two parties, the Conservatives and Labour, have dominated the political landscape in the United Kingdom. Their governments tend to be strong; the country's first-pastthe-post electoral system contributes to strong parliamentary majorities and helps the ruling party implement its policies. As a result, political cycles tend to be more pronounced as parties are rewarded or punished for their economic performance (Potrafke, 2012). Yet, surprisingly, after a century of governance by the Conservatives and Labour, there is a little academic research on the question: Which party has been better for economic growth?

This paucity becomes even more perplexing by the importance of the issue in question - opinion polls indicate that UK voters consider the economic performance of each party as a key factor in their political decision-making (Prescott-Smith, 2019). Undeterred by this lack of research, however, the British public has already reached its conclusions. The Conservatives enjoy a clear political advantage as the party expected to manage the economy better. This belief is shared by a sizable percentage of Labour voters themselves (Smith, 2019) and could possibly explain the electoral predominance of the Conservative party in UK politics (see Table 1).

\footnotetext{
* Corresponding author. E-mail: a.tziamalis@shu.ac.uk.

Citation: Algarhi, A. S., and Tziamalis, A (2021) Does the UK economy grow faster under a Conservative or Labour government?, Economics and Business Letters, 10(2), 95-101.
}

DOI: $10.17811 /$ ebl.10.2.2021.95-101 
Nordhaus (1975) and Hibbs (1977) use the short-term Phillips curve to showcase the effect of partisan politics on macroeconomic outcomes. In their analyses, left-wing parties are thought to please an electorate which values high employment while right-wing parties please a political base which prioritises low inflation. Further, Alesina and Roubini (1992) apply a rational expectations augmented approach to partisan politics and found that changes in output are only temporary. Empirical evidence offers some validation of theory. Short-term economic growth in OECD countries is found to be somewhat higher under leftwing than rightwing governments (Potrafke, 2017). A finding that is stronger in countries with two-party systems (Potrafke 2012), in the UK.

Assessing a government's impact on economic growth is not a straightforward exercise, however. A newly elected government will need time to legislate for and implement its new policies. Even more time will be needed for these policies to bear fruit. Indeed, several studies have emphasised that policy time lags can exceed four quarters (Campbell, 2012; Comiskey and Marsh, 2010; Kane, 2017). On the other hand, it can be argued that rational expectations can shorten time lags: economic players could adjust their economic behaviour ahead of the implementation of an economic policy. However, Blinder and Watson (2016) whose main finding is that Democrats come with a positive and statistically significant advantage over the Republicans in terms of US real GDP growth, argue in favour of a one-quarter lag. In this study, we bypass this contentious issue by exploring lags 1 through 8 in addition to an overlapping technique.

\section{Data and analysis}

We use quarterly real GDP data from the Office for National Statistics over the period: 1955Q12019Q2. The quarter-on-quarter growth rates are calculated by taking the natural logarithm of the ratio of two consecutive GDP quarters, totalling 257 quarters. We allocate each quarter to a total of 17 Conservative and Labour governments.

Table 1. Average annualised growth rates by general elections.

\begin{tabular}{lrrr}
\hline \hline & Period & Growth rate (\%) & Growth rank \\
\hline \hline Conservatives & & $\mathbf{2 . 5}$ & \\
Eden-Macmillan 1* & $1955: 2-1959: 3$ & 2.43 & 9 \\
Macmillan 2-Douglas-Home & $1959: 4-1964: 3$ & 3.97 & 2 \\
Heath & $1970: 3-1974: 1$ & 2.85 & 6 \\
Thatcher 1 & $1979: 2-1983: 2$ & 1.21 & 16 \\
Thatcher 2 & $1983: 3-1987: 2$ & 3.57 & 3 \\
Thatcher 3-Major 1 & $1987: 3-1992: 1$ & 1.88 & 13 \\
Major 2 & $1992: 2-1997: 1$ & 2.84 & 7 \\
Cameron- Clegg & $2010: 2-2015: 1$ & 2.05 & 10 \\
Cameron 2-May 1 & $2015: 2-2017: 2$ & 2.02 & 11 \\
May 2- May 3 & $2017: 3-2019: 2$ & 1.32 & 15 \\
\hline Labour & & $\mathbf{2 . 2 6}$ & \\
Wilson 1 & & 1.96 & 12 \\
Wilson 2 & $1964: 4-1966-1$ & 3.10 & 5 \\
Wilson 3 & $1966: 2-1970: 2$ & 4.20 & 1 \\
Wilson 4-Callaghan & $1974: 2-1974: 3$ & 1.83 & 14 \\
Blair 1 & $1974: 4-1979: 1$ & 3.40 & 4 \\
Blair 2 & $1997: 2-2001: 2$ & 2.53 & 8 \\
Blair 3-Brown & $2001: 3-2005: 1$ & 0.65 & 17 \\
\hline \hline
\end{tabular}

Note: *Denotes the number of the government. 
Table 2. Summary statistics of real GDP growth rates.

\begin{tabular}{lrr}
\hline \hline & Conservative & Labour \\
\hline \hline $\mathrm{N}$ & 162 & 95 \\
Mean & 0.62 & 0.56 \\
Median & 0.58 & 0.62 \\
Std. Dev. & 1.02 & 0.86 \\
Skew. & 0.55 & -0.32 \\
Kurtosis & 6.80 & 5.24 \\
minimum & $-2.78(1974: 1)$ & $-2.09(2008: 4)$ \\
maximum & $4.86(1973: 1)$ & $3.60(1968: 1)$ \\
Recession quarters & 17 & 7 \\
\hline \hline
\end{tabular}

Table 1 shows the average annualised growth rate for each government. We note how close the economic performance of the two ruling parties has been overall. Since 1955, real GDP grew by an annualised average of $2.41 \%$, with the Conservatives achieving a slightly better growth rate than Labour (2.5\% versus $2.26 \%$ ). However, this difference between the two parties is statistically insignificant.

Table 2 presents quarterly statistics for each political party. We note the relative political dominance of the Conservative party which has ruled for a total of 162 quarters, as opposed to 95 quarters for Labour. Another interesting finding is that even though the Conservatives achieved a slightly higher mean growth per quarter (0.62 versus 0.56$)$, Labour achieved a slightly higher median $(0.62$ versus 0.58$)$. None of the two differences is statistically significant but the discrepancy between mean and median hints at the presence of negative outliers in the data.

The histograms in Figure 1 detect skewness in our data and complement Table 2. We observe that Labour achieve a higher concentration of quarters with positive growth while the Conservatives show higher deviation. Indeed, despite the 2008 recession during Labour's watch, from a total of 24 quarters which can be classified as in recession, only 7 came under Labour versus 17 under the Conservatives.

With a higher median value and fewer recession quarters, can it be that the Labour party is more consistent in managing the economy than the Conservatives? We turn our analysis to the performance of specific governments since 1955; Figure 2 presents the average annualised growth between general elections. What captures our attention is the particularly low growth during the five years of the Blair-Brown government (2005-2010), an administration faced with the largely external shock of the 2008 Financial Crisis.

Figure 1. Histogram of real GDP growth rates.

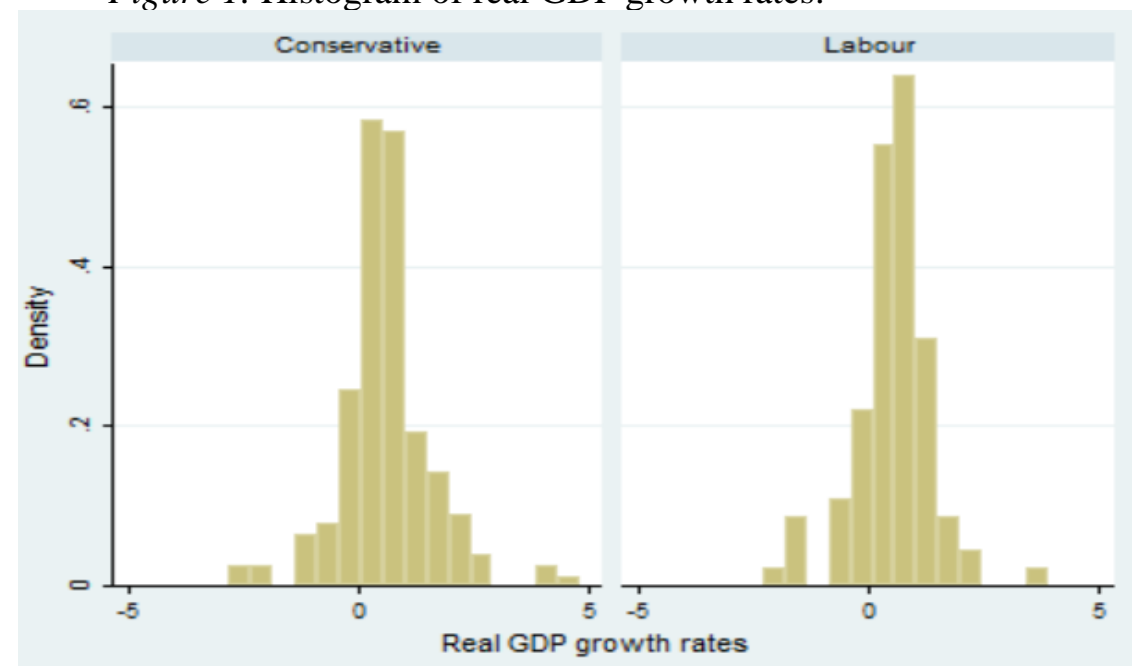


Figure 2. Average annualized GDP growth between general elections.

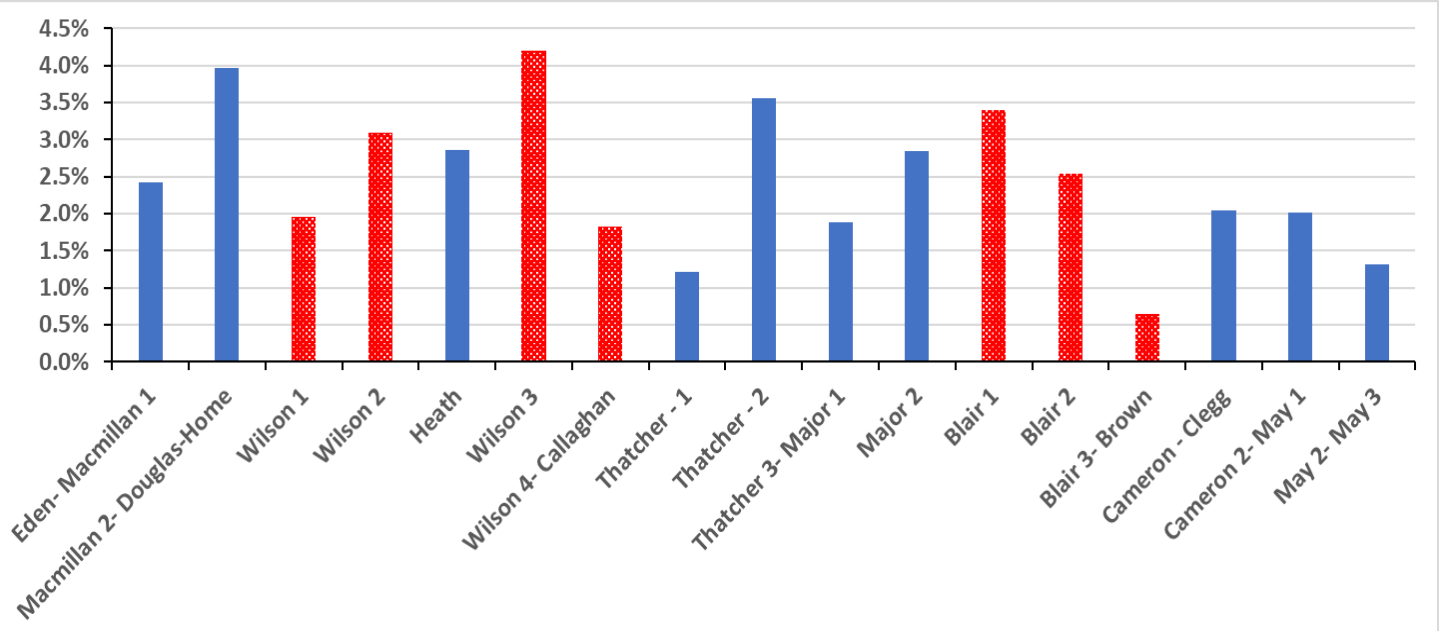

Figure 3. Average annualized GDP growth by governments.

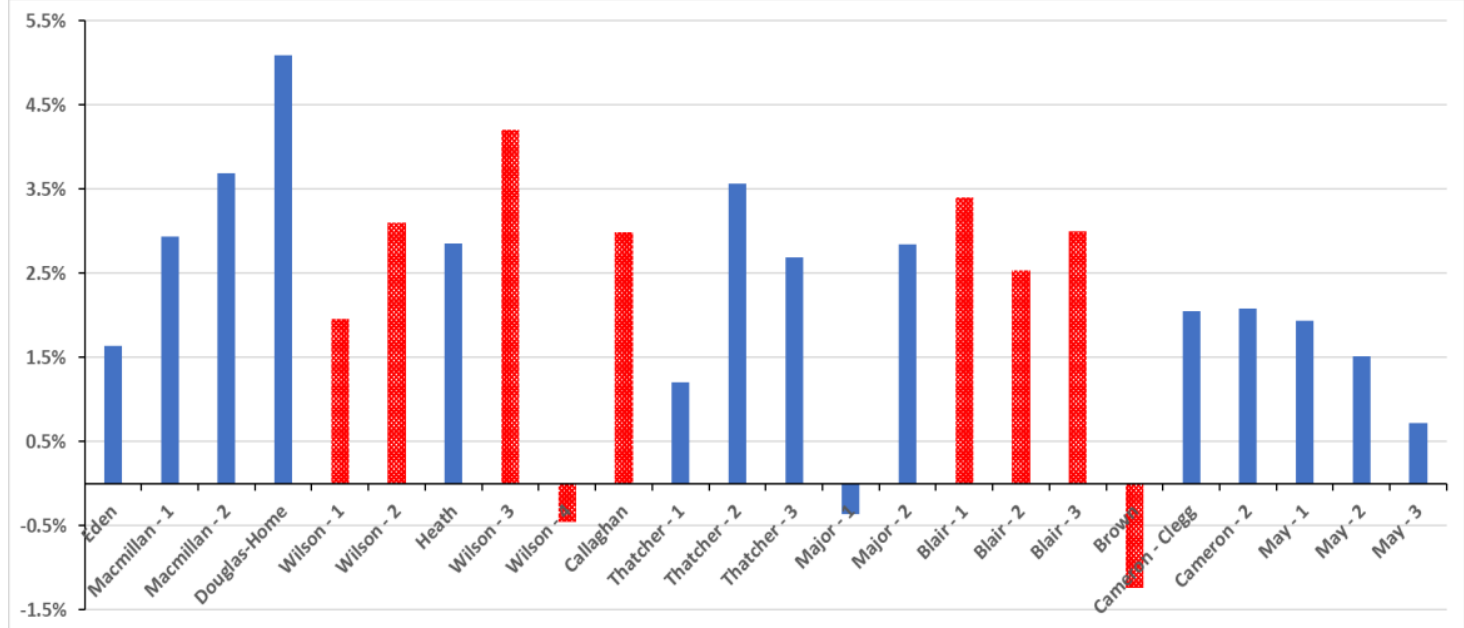

Figure 3 confirms our suspicion. When we unpack the 2005-2010 period, we find that the Blair government (2005-2007) had in fact an average growth rate of more than $3 \%$ while the Brown government (2007-2010) endured 5 quarters of negative growth due to the 2008 Financial Crisis. Consequently, an important second point is that despite the worst recession in 90 years weighing against Labour, the economy still shows higher volatility under Conservative governments - a fact corroborated by Table 2 which shows higher standard deviation for the Conservatives.

Especially if we disregarded the 2008 Financial Crisis as an external shock, Labour preside over just 2 recession quarters since 1955, with average annualised growth of $2.66 \%$. In like manner, if we omitted the 3 quarters of recession during the Heath administration, following the 1973 oil shock, Conservative governments would achieve average annualised growth of $2.65 \%$ and preside over 14 recession quarters.

The two main findings in our analysis so far are that: first, the difference in the GDP growth between the two main parties is rather small and statistically insignificant (see Table 2); and second, Labour governments are more consistent in their performance and manage to tackle recessions better. But what if the performance of a newly elected government is mitigated by the on-going policies of the previous administration? Those who follow politics, not just in the UK but globally, should be well aware of the maxim: "We inherited a bad situation from the previous government". The next section seeks to address the verity of such a statement in the UK. 


\section{Time lag scenarios and overlapping technique}

To assess whether the economic performance of either party improves as a newly elected government is given time to implement its new policies, we incorporate time-lags and overlapping quarters into our analysis.

Figure 4. Average annualized GDP growth rates over different lagged quarters.

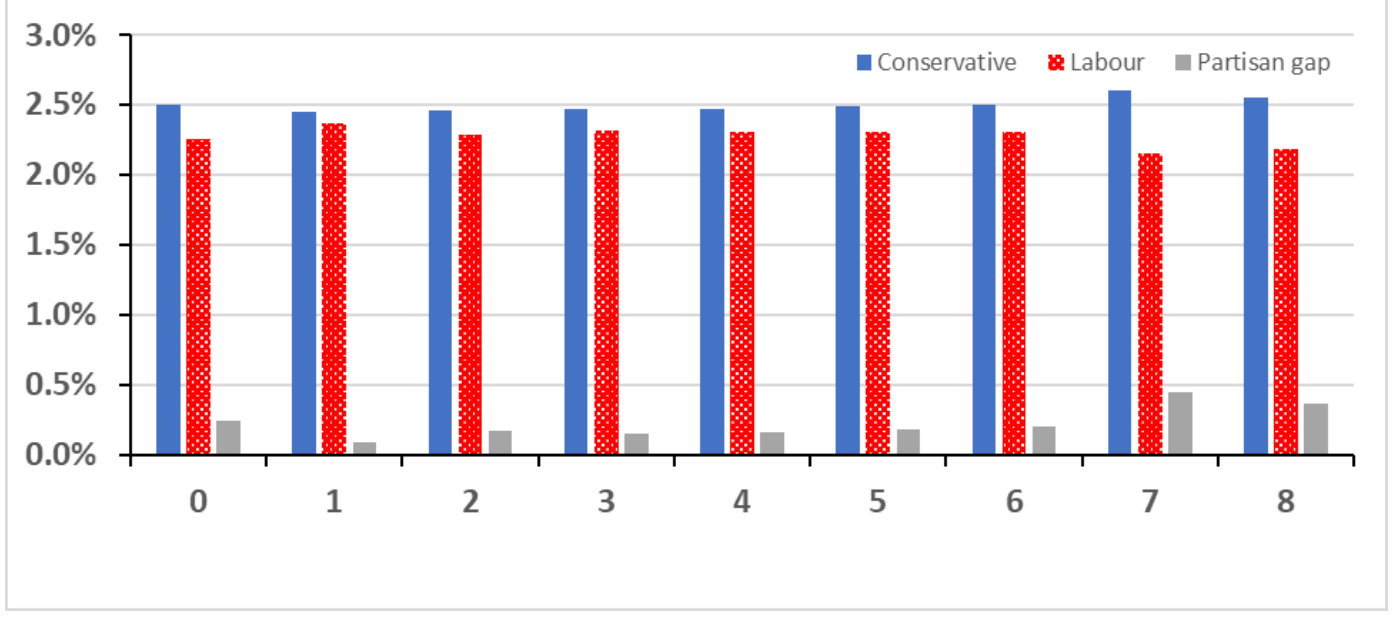

In the case of time-lags, we credit the economic performance of a newly elected government in the first quarters in office to the previous government. We explore the difference in real growth for up to lag 8 (see Figure 4). We note that the already statistically insignificant gap in real GDP growth between the Conservatives and Labour tends to close even further up until 6 quarters. In the $7^{\text {th }}$ and $8^{\text {th }}$ quarter however, the gap seems to widen which is consistent with political scientists' recommendation of lags of one year or more (Kane, 2017). To assess whether this gap becomes statistically significant at lags of seven and eight quarters, first we create a partisan dummy variable that takes on values of 1 for a Conservative government and 0 for Labour. Then, we run econometric tests using autoregressive specification of the growth rate. Table 3 shows that the partisan dummy remains insignificant for both lags.

Table 3. The effect of UK political parties on economic growth, 1955-2019.

\begin{tabular}{lrr}
\hline \hline & Dependent variable: Real GDP growth & \\
\hline Independent variables & & $0.236^{* * *}$ \\
\hline Real GDP growth (1-quarter lag) & - & $(0.064)$ \\
& & 0.100 \\
Real GDP growth (2-quarter lag) & - & $(0.065)$ \\
& & $0.162^{* *}$ \\
Real GDP growth (3-quarter lag) & & $(0.063)$ \\
& 0.197 & 0.126 \\
Conservative government (7-quarter lag) & $(0.399)$ & $(0.383)$ \\
& 0.081 & 0.011 \\
Conservative government (8-quarter lag) & $(0.399)$ & $(0.384)$ \\
& & $0.499 * * *$ \\
Constant & 246 & 246 \\
$\mathrm{~N}$ & & 246 \\
\hline \hline
\end{tabular}

Note: $* * *, * *$ and $*$ denote the level of significance at $1 \%, 5 \%$ and $10 \%$ respectively. Standard errors in parentheses. 
Our time-lag analysis has not generated a clear winner between the two UK parties. In light of this, we resort to an overlapping technique to further explore the topic. This technique implicitly acknowledges that new governments can have an effect on the economy from their first day in office, even if this change is attributed to a market sentiment rather than new legislation. Yet, this initial impact can only be limited; new fiscal and monetary policies may well take months or years to yield results (Comiskey and Marsh, 2012). To simulate this gradual process, we adopt Kane's (2017) "annual thirds method", in which the new government is economically responsible for just one-third of growth in Year 1, two-thirds in Year 2 and assumes full responsibility only from Year 3. This technique creates an overlapping effect between previous and newly elected governments.

Table 4. Average annualised growth rates by prime ministers using different approaches.

\begin{tabular}{lrrrrr}
\hline \hline $\begin{array}{l}\text { Incoming party, prime } \\
\text { minister and year }\end{array}$ & $\begin{array}{r}\text { N. of } \\
\text { quarters }\end{array}$ & $\begin{array}{r}\text { No } \\
\text { lag }\end{array}$ & Lag 1 & Lag 8 & Overlapping \\
\hline Conservatives & & & & & $\mathbf{2 . 4 8}$ \\
Eden, 1955:2 & 7 & 1.63 & 3.21 & 0.96 & 1.57 \\
Macmillan, 1957:1 & 27 & 3.38 & 3.42 & 3.91 & 3.73 \\
Douglas-Home, 1963:4 & 4 & 5.09 & 4.30 & 1.69 & 2.97 \\
Heath, 1970:3 & 15 & 2.85 & 2.97 & 1.08 & 2.05 \\
Thatcher, 1979:2 & 47 & 2.45 & 2.05 & 2.62 & 2.43 \\
Major, 1991:1 & 25 & 2.20 & 2.38 & 3.19 & 2.75 \\
Cameron, 2010:2 & 25 & 2.06 & 1.97 & 2.00 & 2.02 \\
May, 2016:2 & 12 & 1.52 & 1.50 & 1.30 & 0.94 \\
\hline Labour & & & & & $\mathbf{2 . 2 5}$ \\
Wilson, 1964:4 & 23 & 2.80 & 2.71 & 3.53 & 3.10 \\
Wilson, 1974:2 & 8 & 0.69 & -0.11 & 2.93 & 1.86 \\
Callaghan, 1976:2 & 12 & 2.99 & 4.53 & 0.64 & 2.08 \\
Blair, 1997:2 & 41 & 3.00 & 2.99 & 1.88 & 2.54 \\
Brown, 2007:3 & 11 & -1.24 & -1.16 & 1.68 & -0.14 \\
\hline \hline
\end{tabular}

Table 4 summarises our findings. The annualised growth rates for the two parties are almost identical to those in Table 1 and remain statistically insignificant. Our main finding in Section 2 is reinforced: the economy grows at a very similar pace under Labour and the Conservatives.

Interestingly however, the overlapping technique suggested by Kane (2017) alters our perception of responsibility for some of the bleakest economic times in the UK. We note that Wilson's short-lived fourth government may not have been as negative as we thought, and that perhaps the recession during Major's administration should be partly attributed to Thatcher's previous government. Finally, Cameron's initial success was perhaps bolstered by Brown's expansionary policies in his effort to fight the 2008 Financial Crisis.

\section{Conclusion}

We examine the growth of the UK economy under the administration of the Conservatives and Labour, the two political parties which have alternated in power since 1955. Our main finding is that the UK economy has grown with a similar pace under either government, however Labour administrations seem to do better in tackling recessions and show a more consistent performance. Labour's advantage becomes more pronounced if we discount the effect of the 2008 Financial Crisis.

Far from being exhaustive, our research aims at opening an impartial and objective dialogue on the economic performance of the political parties that govern the UK. We believe that 
academic research can dispel myths and assist citizens in selecting their governments. Further research is needed to explore parties' records on more economic and non-economic indicators such as unemployment, inflation, labour productivity, environmental degradation and social cohesion. In addition, research could explore the economic performance of Left/Right in more democracies, drawing parallels where possible and adding value to this emerging field of scholarship.

\section{References}

Alesina, A. and Roubini, N. (1992) Political Cycles in OECD Economies, The Review of Economic Studies, 59(4), 663-688.

Blinder, A. S., and Watson, M. W. (2016) Presidents and the US Economy: An Econometric Exploration, American Economic Review, 106(4),1015-1045.

Campbell, J. E. (2012) The President's Economy: Parity in Presidential Party Performance, Presidential Studies Quarterly, 42(4), 811-818.

Comiskey, M., and Marsh, L. (2012) Presidents, Parties and the Business Cycle, Presidential Studies Quarterly, 42(1), 40-59.

Hibbs, D. A. (1977) Political parties and Macroeconomic Policy, American Political Science Review, 70(4), 1467-1487.

Kane, T. (2017) Presidents and the US Economy from 1949 to 2016, Hoover Institution Economics Working Papers, 17101.

Nordhaus, W. D. (1975) The Political Business Cycle, The Review of Economic Studies, 42(2), 169-190.

Potrafke, N. (2012) Political Cycles and Economic Performance in OECD Countries: Empirical Evidence from 1951-2006, Public Choice, 150, 155-179.

Potrafke, N. (2017) Partisan Politics: The Empirical Evidence from OECD Panel Studies. Journal of Comparative Economics, 45(4), 712-750.

Prescott-Smith, Sarah (2019, November 7) Which issues will decide the general election?, retrieved from http://yougov.co.uk

Smith, Matthew (2019, November 12) Labour economic policies are popular, so why aren't Labour?, retrieved from http://yougov.co.uk. 